\title{
Officialization and Linguistic Acculturation of Spanish in the United States Catholic Church
}

Antonio Medina-Rivera

Cleveland State University, a.medinarivera@csuohio.edu

Follow this and additional works at: https://engagedscholarship.csuohio.edu/clmlang_facpub

Part of the Latin American Literature Commons, Spanish Linguistics Commons, and the Spanish Literature Commons

How does access to this work benefit you? Let us know!

Publisher's Statement

John Benjamins Publishing Company should be contacted for permission to re-use or reprint the material in any form.

\section{Recommended Citation}

Medina-Rivera, Antonio. 2012. "Officialization and linguistic acculturation of Spanish in the United States Catholic Church." Language Problems \& Language Planning 36, no. 2: 149-165.

This Article is brought to you for free and open access by the Department of World Languages, Literatures, and Cultures at EngagedScholarship@CSU. It has been accepted for inclusion in World Languages, Literatures, and Cultures Faculty Publications by an authorized administrator of EngagedScholarship@CSU. For more information, please contact library.es@csuohio.edu. 


\title{
Officialization and linguistic acculturation of Spanish in the United States Catholic Church
}

\author{
Antonio Medina-Rivera \\ Cleveland State University
}

The present investigation brings to light some of the changes associated with the use of English and Spanish in the US Catholic Church. The first part is an examination of the process of officialization from a historical perspective, acknowledging the impact of some groups or associations in the use of vernacular languages within the Church. The second part examines the role of acculturation during this process of officialization; and the final section analyzes the use of inclusive language in the Church, as an attempt to have a more gender-balanced institution. These three elements serve to provide a more complete perspective of the reality, expansion, revitalization and maintenance of the Spanish language in the United States. The article also reveals some of the language planning policies (direct and indirect) that have made an impact on the use of Spanish within US Catholicism.

Keywords: US Spanish language, Roman Catholic Church, language planning, inclusive language, acculturation, lexical innovation, language and religion

According to the Committee on Liturgy of the United States Conference of Catholic Bishops (USCCB), Spanish is considered an official language within the US Catholic Church. English, Latin and some Native-American languages share this status with Spanish. Although there is more than one official language, English is the language of preference when the USCCB meets, though its incorporation in the liturgy is as recent as the incorporation of Spanish. Latin is still commonly used for solemn or extraordinary ceremonies or for an international audience, and is still a common language of celebration, especially in some of the parishes of the northeastern United States. The use of Native-American languages is more limited, whereas the use of Spanish is growing at an unprecedented pace.

Besides finding a space as an official language, Spanish has had to assimilate elements of mainstream Catholicism in order to maintain respect and recognition. Some of these elements of acculturation involve incorporation of new words into 
the language and the use of a more inclusive language. New words help to reflect the reality of ministries and services provided by mainstream Catholicism; inclusive language is a way to recognize the presence of women within the church and to incorporate many of the changes that the promoters of the inclusive language movement have included in American English during the past two decades.

The purpose of the present investigation is to bring to light some of the changes associated with the use of English and Spanish in the US Catholic Church, thereby providing a new perspective on the expansion, revitalization and maintenance of the Spanish language in the United States. First, I discuss the process of officialization from a historical perspective, acknowledging the impact of some groups or associations on the use of vernacular languages within the church. Secondly, I examine the role of linguistic acculturation, with a special emphasis on lexical innovation and the incorporation of inclusive language. Examination of officialization and linguistic acculturation puts into evidence some of the language planning policies (direct and indirect) that have had an impact on the use of Spanish within US Catholicism.

\section{The process of officialization}

The United States of America makes no mention of an official language in its constitution, although in practice English is undisputedly the national language of the country. Bernard Spolsky defines language policy as "all the language practices, beliefs and management decisions of a community or polity" (2004:9). Some of these language practices are explicit, and others are implicit "in which case there can be honest disagreement as to what is the real policy of a community" (Spolsky 2004:39). There are policies clearly stated in the constitution of a country that appear only on paper but not in practice, as is the case with some indigenous languages in the world. While there might be two or more official languages, in practice one of the languages is "more official" than the other.

Although English and Spanish share official status in the US Catholic Church, the degree of "officiality" is clearly questionable. While many language practices reveal the importance, growth and development of Spanish within the Church, some Church authorities remain unaware of this reality and others simply ignore it.

\section{A historical perspective}

Spolsky observes that "little scholarly attention has been paid to the close interactions between religion (whether beliefs or practices) and language policy" 
(2004:48). Most books and articles on the history of the Catholic Church in the United States do not adequately address the issue of language use or language policies. This article seeks to remedy this neglect. Most of the information in this section comes from unpublished sources available in the University of Notre Dame's archives (UND).

Before 1965, and the conclusion of the Second Vatican Council (Vatican II), use of English or any other vernacular language in the US Catholic liturgy was very limited. Latin was very much engraved in US Catholic tradition and the possibility of any change seemed very remote, even though other countries of the world such as Poland, and some South American countries, started incorporating the use of their vernacular before Vatican II. In 1943, the Rev. H. A. Reinhold from the Diocese of Pittsburgh started a group called the St. Jerome Society, whose purpose was to promote the use of vernacular languages in the liturgy. In 1948 this group changed its name to the Vernacular Society. In 1963, Colonel John K. RossDuggan, one of the most distinguished leaders of this organization, stressed the need for vernacular languages:

We need to align ourselves with our contemporaries in all the vernacular countries - Germany, Holland, France, Jugo-Slavia, Austria, Latin America, the Mission-lands, India, and so forth so that the full majority force of the majority opinion in favor of the use of national languages may be expressed, felt, have effect on the conservative Curia and others. (UND-Archives, Letter to Chief Justice G.E. Tritschler, May 28, 1963)

By the time this letter was written, many national churches, though not that of the United States, had adopted the use of vernaculars and incorporated hymns written in their national languages. The Traditionalist Movement and the Latin Mass Society were the main opponents of the use of English, or any other languages besides Latin, in the liturgy - opposition that continued even after the conclusion of Vatican II. A clipping from the New York Times (February 4, 1967) in the UND Archives confirms the fact that, by the time of Ross-Duggan's death in 1967, the vernacular was in use in the celebration of all sacraments and benedictions, and in most parts of the mass, with the exception of the most solemn part, which was at this time still celebrated in Latin.

The use of Spanish in the US liturgy came in conjunction with the incorporation of English. By 1967, the Hispanic presence in some of the main cities of the United States was already noticeable - Mexicans in the southwestern states and Illinois, and Puerto Ricans in New York and other areas of the northeast. Many Hispanic communities were established years before in areas of the southwest, prior to the US conquest of the west during the nineteenth century. In these communities the use of Spanish in some parts of the liturgy was already normal. Dolan 
(1992:374) indicates that by 1925 there were two churches in Chicago offering some services in Spanish. At the time, the dioceses of Chicago and Los Angeles created "Americanization" programs to help the Hispanic community assimilate within mainstream Catholicism and encouraging English as the language of communication:

In keeping with the spirit of the 1920s, the church in Los Angeles inaugurated and extensive Americanization program. The bishop of Los Angeles, John Cantwell, was a big supporter of this movement and received help from Knights of Columbus, who published a civics catechism in Spanish. Cantwell's successor, Francis McIntire, continued this emphasis on Americanization; during his episcopacy, the parish school became the principal agency in the Americanization of the Mexican population. (Dolan 1992:373-374)

In Chicago, Archbishop George Mundelein, "a staunch supporter of 100 percent Americanization" (Dolan 1992:300), used the parochial school as an Americanization tool. Some of the "melting pot" ideas of the time may seem racist, and inconceivable in today's environment, but they reflect the mentality during those years of massive European immigration into the United States. Hence the ideas of Bishops Cantwell and Mundelein were very well received by most Catholics. However, opposition was also evident, especially among German and Polish Catholics, who saw such linguistic initiatives as an attack on mainstream European culture and identity. The Irish Catholic tradition and style of celebration, already ingrained among US Catholics, was imposed on many of the new immigrants coming to the United States during the nineteenth and twentieth centuries.

The Americanization Project started by Mundelein, Cantwell and McIntire did not have the immediate success they were expecting because of the constant increase in Hispanic immigration during the following decades. By the time of the US Census of 2000, Hispanics were the largest minority group in the country, with over twelve percent of the population. Among Catholics the percentage of Hispanics was even higher: forty percent of the Catholic population, according to the US Bishops' Committee on Hispanic Affairs (1999).

Another factor leading to the non-incorporation of Hispanics within mainstream Catholicism was the racial and cultural issue. In many churches, especially in the east, Puerto Ricans and Mexicans had no other choice but to sit in the back or to celebrate Spanish-language liturgies in church basements or school auditoriums. Such discrimination contributed significantly to the separation of Hispanic Catholicism and mainstream Catholicism in the United States. Matovina and Poyo (2000:98-99) observe that Protestant and Evangelical churches proliferated among Hispanics during that time: 
For example, in a 1951 report on the religious conditions of Puerto Rican in New York, Encarnación Padilla de Armas and other Puerto Rican women opined that the "most striking aspect of the Puerto Rican situation is the constant and energetic activity of Protestants." Their report emphasized that Protestants offered extensive ministries in Spanish and that some eight hundred Puerto Rican ministers served in New York, where at that time was not a single Catholic priest of Puerto Rican origin.

One pastor in the city of Bethlehem, Pennsylvania, explained to me during an interview that the reason why the church started offering services in Spanish in cities such as Bethlehem and Allentown was because Protestant churches in the area were already doing so. In other words, the Catholic Church felt pressure to start recognizing the presence of Hispanics, welcoming them into local churches, and offering liturgies and services in their own language.

The Knights of Columbus, which participated in the Americanization Project of the 1920s, eventually played an important role in supporting Hispanic Catholics in the United States. During their 1950 State Convention in El Paso, Texas, the Knights of Columbus wrote the following letter to the Rev. T. J. Radtke:

It is unfair to apply the standards of our Catholics as generally interpreted in the United States to the people whose Catholic tradition is entirely different. We have a tendency in the United States to pride ourselves on our strict Catholicity, that we have the best in the world. (UND Archives, Letter to Rev. T. J. Radtke, Executive Secretary for the Bishops' Committee for the Spanish Speaking)

This initiative, in addition to many other anonymous efforts during this time, concluded with the transferring of the Office for the Bishops' Committee for the Spanish Speaking from San Antonio to Washington, DC. This was significant, since the main offices of the Catholic Church are located in that city. Today the office is officially named the Secretariat for Hispanic Affairs.

While for many years the Puerto Rican community struggled for visibility within the Church, the history of the southwestern church was very different. In 1972, the founding of the Mexican American Cultural Center (MACC) in San Antonio, Texas, became an important event in the development of the Hispanic church. This center created many initiatives, programs and materials to help the spiritual growth and formation of many Hispanics in the US, while respecting the idiosyncrasies and church experience of the people of Mexican origin living in the area. The efforts of San Antonio's bishop Anthony Lucey and his successor Patricio Flores had an important impact in maintaining the Spanish language in the church and in the community. 


\section{The status of the Spanish language today}

The 1980s were a period of special importance for the development and growth of Spanish within the US Catholic Church. The creation of the Hispanic Liturgy Subcommittee in 1982 (Dolan \& Deck 1994), part of the Liturgy Committee of the USCCB, was essential to elevate the status of Spanish as one of the three important languages of liturgy in the United States (the other two being Latin and English). At issue was not just the possibility of establishing liturgies in different national languages, such as Italian or Polish (as had been the tradition with different national churches in different cities of the US), but the possibility of Spanish being recognized as a language of almost equal importance with English and Latin:

Through the work of this subcommittee the U.S. bishops would petition Rome to consider Spanish as a liturgical language proper to the United States in 1984. Great satisfaction would be felt by the members of the Hispanic liturgy subcommittee in January of 1985 when Rome confirmed Spanish as a liturgical language in the United States. This action gave the National Conference of Catholic Bishops authority over its own liturgical Spanish texts and freed it from the use of a confusing array of liturgical books produced by other Spanish-speaking national bishops' conferences. From this base two significant accomplishments would be made: the development of the Sacramentary (the book of prayers used by priest at the Eucharist) adapted for the U.S. Hispanic community and the official recognition of the United States as a Spanish-speaking country. (Dolan \& Deck 1994: 374)

From a global point of view the recognition of the US as a Spanish-speaking country was an important development. This language policy helped to unify the US Catholic Church by giving recognition to the Spanish-speaking community, which today forms more than forty percent of the total Catholic population in the United States. ${ }^{1}$ Besides the Sacramentary the subcommittee also published in Spanish the Lectionary of the Mass (based on the Mexican Lectionary), the Book of Blessings, the Funeral Rite, the Rite of Marriage, and the Administration of Communion for the Sick. The USCCB has also published other books and documents in Spanish, and all documents and materials originally written in English are almost simultaneously translated into Spanish as well.

\section{The process of linguistic acculturation}

With the officialization of the Spanish language and the consequent growth in its use, the US Catholic Church continues to go through a process of adjustment. Addressing language planning in religion, Spolsky (2004:51) indicates that "Given the make up of the particular religion, the language practices involved may vary 
very considerably." He singles out the translation of sacred texts, hymns, sermons, and other religious texts. In the case of Hispanics within the US Catholic Church, one of the most notable adjustments is related to lexical innovation required by the use of Spanish in a United States context, including the publication of materials in Spanish for a Hispanic audience. A second adjustment, to incorporate a feminist point of view, is related to changes in vocabulary that respond to a more inclusive use of the language.

\section{Methodology}

To examine the impact of lexical innovation and the use of inclusive language, I decided to consult some primary sources and to prepare a questionnaire. $\mathrm{My}$ primary resources were Spanish-language books published by Catholic publishers in the United States, particularly St. Mary's Press, Ligouri Press, and Brown-Roa. Originally most of the religious books and materials necessary for the formation of Hispanic Catholics in the US came from Mexico or Spain. These books did not reflect the reality and idiosyncrasies of Hispanics living in the United States. During the mid 1980s, St. Mary's Press, a publisher dedicated to youth ministry materials, was the first publisher to develop a complete project to produce materials in Spanish for a US Hispanic audience.

I decided to concentrate especially on three books produced by St. Mary's Press, since they were more pastoral than pious in nature, and consequently more appropriate for a linguistic investigation: ${ }^{2}$ La juventud hispana y la respuesta pastoral de la iglesia/Hispanic Youth and the Pastoral Response of the Church (1994), En alianza con Dios/In Covenant with God (1998), and Seguidores de Jesús/Followers of Jesus (2000). These books were originally written in Spanish and translated into English by the St. Mary's Press Hispanic team. All members of the team live in the United States, but were originally from Mexico, Chile, Spain, and Puerto Rico. In addition to the textbooks, I included a songbook, Flor $y$ canto (1989), published by Oregon Catholic Press. This songbook is the most popular among US Hispanics.

\section{Lexical innovation}

In addition to consulting written materials, I decided to create a questionnaire with a list of pastoral terms, to test the meaning and usage of these terms with Spanish speakers living in Latin America. The Spanish speakers selected for this study were religious or pastoral ministers who were very well informed about language uses within the community. I contacted all of the speakers through different dioceses across Latin America, and others were directly referred to me by Hispanic Church leaders in the United States. After sending the questionnaire to at least one 
diocese for each of the Spanish-speaking countries in Latin America and Spain, I received responses from Chile, Mexico, Colombia, and Puerto Rico. To participate in the questionnaire the speakers had to be native speakers of Spanish and had to be working directly with the Catholic Church. The questionnaire consisted of twenty words which I knew were problematic for the St. Mary's Press team during the time when they were producing their texts both in English and Spanish. The participants had to classify each of these words using the following guide:

1. This term is not used in our pastoral setting.

2. This term is used with the same meaning.

3. This term is used with another meaning.

Although most of these words appear in Spanish dictionaries, their semantic extension may make them lexical innovations. The question to the participants was not whether they knew the meaning of the word or not, but whether they used each term within their pastoral setting. After completing the questionnaires I had some additional e-mail contact with my participants to make sure all the information provided was clear and accurate.

Lexical innovation is one of the significant elements identifiable in the books produced by the Catholic publishers. Such innovation is needed to name realities and concepts that are used differently in the churches of Spain and Latin America, and also to create words with no complete equivalence in the other language.

Table 1 shows the level of acceptance for each one of the twenty terms, with the responses of two speakers (priests and laypeople who work in the church) from each of the four countries. I decided to include two words which I was sure were in common use in the Latin American Catholic Church: "pastoral de conjunto" (number 3 in the table) and "iglesia" (number 5). The term "pastoral de conjunto" became very popular during the late 1970s in Latin America and has no English equivalent, although it has been translated as "joint pastoral effort" by members of St. Mary's Press editorial team or "collaborative ministry" by other groups. The term "iglesia" is not regularly used with the meaning of "parish" in Latin America (e.g. Our Lady of Perpetual Help Church would be "Parroquia Nuestra Señora del Perpetuo Socorro" instead of "Iglesia Nuestra..."). In American English the word "parish" exists; however, the term "church" is more frequently used in that context. All the participants of the questionnaire accepted the word with the meaning provided in Spanish. My general observation is that the word "iglesia" is more common among the Hispanic churches in the US, and the word "parroquia" is more common in Latin America. 
Table 1. Level of Acceptance for Each Term

\begin{tabular}{|c|c|c|c|c|c|c|c|c|}
\hline \multirow{2}{*}{$\begin{array}{l}\text { Term } \\
\text { 1. joven adulto/young adult }\end{array}$} & \multicolumn{2}{|c|}{$\begin{array}{l}\text { Chile } \\
2 \text { speakers }\end{array}$} & \multicolumn{2}{|c|}{$\begin{array}{l}\text { Colombia } \\
2 \text { speakers } \\
\end{array}$} & \multicolumn{2}{|c|}{$\begin{array}{l}\text { Mexico } \\
2 \text { speakers }\end{array}$} & \multicolumn{2}{|c|}{$\begin{array}{l}\text { Puerto Rico } \\
2 \text { speakers }\end{array}$} \\
\hline & 1 & 2 & 2 & 1 & 1 & 1 & 1 & 1 \\
\hline 2. ministro de jóvenes/youth minister & 1 & 1 & 1 & 2 & 1 & 1 & 1 & 1 \\
\hline $\begin{array}{l}\text { 3. pastoral de conjunto/joint pastoral } \\
\text { effort or collaborative ministry }\end{array}$ & 2 & 1 & 2 & 2 & 2 & 2 & 2 & 2 \\
\hline 4. pastoral asociado/pastoral associate & 1 & 1 & 1 & 2 & 1 & 1 & 1 & 1 \\
\hline 5. iglesia/Church & 2 & 2 & 2 & 2 & 2 & 2 & 2 & 2 \\
\hline $\begin{array}{l}\text { 6. ministerio hispano/Hispanic } \\
\text { ministry }\end{array}$ & 1 & 1 & 1 & 1 & 1 & 1 & 1 & 1 \\
\hline 7. joven migrante/migrant youth & 2 & 1 & 2 & 2 & 2 & 1 & 1 & 1 \\
\hline $\begin{array}{l}\text { 8. ministro de pastoral/pastoral } \\
\text { minister }\end{array}$ & 1 & 1 & 1 & 2 & 1 & 1 & 1 & 1 \\
\hline 9. praxis cristiana/Christian praxis & 1 & 2 & 2 & 2 & 1 . & 2 & 1 & 1 \\
\hline $\begin{array}{l}\text { 10. Rito de Iniciación Cristiana para } \\
\text { Adultos/Rite of Christian Initiation } \\
\text { for adults }\end{array}$ & 2 & 2 & 1 & 2 & 1 & 2 & 1 & 1 \\
\hline $\begin{array}{l}\text { 11. Pastoral de adolescents/Teen } \\
\text { Ministry }\end{array}$ & 1 & 2 & 1 & 2 & 2 & 2 & 1 & 1 \\
\hline $\begin{array}{l}\text { 12. Pastoral para Pandilleros/Gang } \\
\text { Ministry }\end{array}$ & 1 & 1 & 1 & 1 & 2 & 2 & 1 & 1 \\
\hline $\begin{array}{l}\text { 13. Pastoral para Migrantes/Migrant } \\
\text { Workers Ministry }\end{array}$ & 2 & 1 & 2 & 1 & 2 & 2 & 1 & 1 \\
\hline $\begin{array}{l}\text { 14. Pastoral juvenil en pequeñas } \\
\text { comunidades/ youth/young adult } \\
\text { ministry organized in small com- } \\
\text { munities }\end{array}$ & 2 & 2 & 2 & 2 & 2 & 2 & 2 & 1 \\
\hline 15. pastor/pastor & 1 & 1 & 1 & 1 & 1 & 1 & 1 & 1 \\
\hline 16. pastor asociado/associate pastor & 1 & 1 & 1 & 1 & 1 & 1 & 1 & 1 \\
\hline 17. rectoría/rectory & 1 & 1 & 1 & 1 & 1 & 3 & 1 & 1 \\
\hline 18. servidores del altar/altar servers & 2 & 2 & 1 & 1 & 1 & 1 & 2 & 1 \\
\hline $\begin{array}{l}\text { 19. ministro de hospitalidad/ } \\
\text { hospitality minister }\end{array}$ & 1 & 1 & 1 & 1 & 1 & 1 & 1 & 1 \\
\hline $\begin{array}{l}\text { 20. consejería pastoral/pastoral } \\
\text { counseling }\end{array}$ & 1 & 1 & 2 & 1 & 1 & 1 & 2 & 1 \\
\hline
\end{tabular}

1: This term is not used in our church setting.

2: This term is used with the same meaning.

3 : This term is used with another meaning. 
The participants in the questionnaire did not accept the terms "ministerio hispano," "pastor," "pastor asociado," "rectoría," or "ministro de hospitalidad" with the meanings provided in the questionnaire, and only one of the participants accepted the terms "ministro de jóvenes," "pastoral asociado," and "ministro de pastoral." Each of these terms are borrowings from English, where the equivalents are "Hispanic ministry," "pastor," "associate pastor," "rectory," "hospitality minister," "youth minister," "pastoral associate," and "pastoral minister," respectively. The terms "pastor" and "rectoría" exist in Spanish but with other meanings. "Pastor" means "shepherd," and in Spanish Catholic usage refers exclusively to a bishop (evangelical churches also use the term to refer to their ministers). In Latin America the word "rector/rectoria" is used in universities to designate the head administrator, and in religious usage to refer to the head administrator or advisor of a seminary. It was surprising that one of the participants accepted the terms "ministro de jóvenes," "pastoral asociado," and "ministro de pastoral." He works for the diocese of Bogotá; I suspect that frequently this type of term develops first in big cities, through international contact. The other participant from Colombia did not accept these terms; he is from a smaller diocese in Quibdo, Colombia.

All the terms above are acceptable translations from English to Spanish, with the exception of "pastoral asociado/pastoral associate." The Spanish version appears to be commonly used in the west of the United States. A better translation might be "asociado pastoral" or "asociado de pastoral," if the word "pastoral" is taken as an adjective or genitive. "Youth minister" is a similar case, translated as "ministro juvenil" or "ministro de jóvenes."

I could not find written evidence for the terms "pastoral asociado," "pastor," "pastor asociado," and "rectoría." On the other hand the terms "ministro de jóvenes" and "ministerio hispano" appeared as borrowings already integrated in Spanish books published by St. Mary's Press.

Only one participant, from Chile, accepted the word "joven adulto" although the person indicated that "adulto joven" is more commonly used. Both terms, besides being interpreted as nouns (e.g. el joven, el adulto) can also be taken as adjectives (e.g. hombre joven, hombre adulto). "Adulto joven" should be the more appropriate form if "young" is taken as the adjective and "adult" as the noun, following regular Spanish word order. Despite this interpretation, the term "joven adulto" is the more commonly used in books published by St. Mary's Press and Instituto Fe $y$ Vida, the main voices in Hispanic youth/young adult ministry in the United States.

The word "migrante" does not exist in Spanish dictionaries. The terms included are "emigrante/emigrant" and "inmigrante/immigrant." In English, the word "migrant," a generic term for both "emigrant" and "immigrant," appears in phrases such as "migrant worker" and has been adopted in US Spanish. Other problematic 
terms are "pastoral de adolescentes" and "pastoral para pandilleros," accepted by the two Mexican speakers. One speaker from Colombia and one from Chile accepted the word "pastoral de adolescentes." One of the speakers commented: "no es que no tengamos pandillas, pero el término no se usa en este contexto" ("the issue is not whether we have gangs or not; however, the term is not used in this context"). I could not find written evidence for the term 'pastoral para pandilleros' within the written materials I had revised.

In Latin America the term "pastoral juvenil" is very popular and does not have an exact equivalent in English, since it covers the definitions of both "youth ministry" and "young adult ministry." Cervantes (2003:10) suggests that the term "pastoral de adolescentes" in Spanish refers only to "youth ministry," although in English the term "teen ministry" also exists and is not exactly a synonym for "youth ministry." As an extension of "pastoral juvenil," the term "pastoral juvenil en pequeñas comunidades"/ "youth/young adult ministry organized in small communities" or "pequeñas comunidades juveniles"/"youth/young adult small communities" is fairly new in Spanish. It is used in every Spanish publication of the St. Mary's Press / Instituto Fe y Vida group, although they give a definition in English that is not exactly understood by mainstream Catholics.

The definition of "Rite of Christian Initiation for Adults" (RCIA) translated as "Rito de Iniciación Cristiana para Adultos" by the Hispanic Liturgy Subcommittee, is understood by Latin American Catholics, but the term does not exist in all Spanish-speaking countries (the two speakers from Mexico, one from Colombia and one from Chile accepted the term). To respond to the particular needs of the US Catholic Church, the USCCB published a translation of the RCIA in 1991 since there was no equivalent in any of the Spanish-speaking countries. The publication of the Leccionario/Lectionary, on the other hand, was based on the Mexican version.

The word "praxis" is commonly used in sociological and political contexts in Latin America. In US English it is also used in the pedagogy/education lexicon. One speaker from Colombia, one from Chile and one from Mexico indicated using the word in their pastoral contexts; however, the Mexican speaker explained that the term has a political connotation, so instead of "praxis cristiana" Mexicans prefer to use "compromiso cristiano/Christian commitment." St. Mary's Press and Instituto Fe y Vida use the term "praxis cristiana" in all their books.

Under the influence of the inclusive language movement, the term "servidor del altar/altar server" is used to substitute for "altar boy." Lastly, the word "consejería pastoral" is of recent use not only in Spanish but in English as well. In the United States 'pastoral counseling' is a field of study at a number of denominational universities, such as Boston College, Loyola University, and Ashland University. The term is easily confused with "spiritual direction," as I perceived in some 
responses to the questionnaire. I could not find the term in print, but it is my understanding that it will appear in future books, and it is included among the list of courses offered by Instituto Fe y Vida.

\section{Inclusive language}

The inclusive language movement, aimed at incorporating words into religious language that reflect a more gender-balanced society, has had a significant effect on many religious groups in the United States. Catholics are no exception. Ronald D. Witherup comments that "inclusive language is an issue which arouses much tension and anxiety, especially in the Roman Catholic Church" (1996:2). What we see in religion is just a consequence of language shift in contemporary English, itself a reflection of changes in realities, mentalities and ideologies. Carson (1998:18) points out that "The most radical feminists have developed liturgies that replace 'Father, Son, and Holy Spirit' with 'Creator, Redeemer, and Sustainer." Some of these changes surfaced as long ago as the publication of The Woman's Bible (1895 and on). Examples that I have been able to gather through my own experiences in liturgies, especially in the area of Los Angeles, include:

- God as a neutral term instead of Father, Lord, He or His. One example is an unofficial version of one of the liturgical prayers, introduced perhaps by feminist nuns in the US: The words "May the Lord accept this sacrifice at your hands for the praise and glory of His name for the good and the good of all His Church" are replaced by: "May God accept this sacrifice at your hand for the praise and glory of God's name, for our good and the good of God's Church."

- "People," "humankind," "human beings" to substitute for the so-called generic forms such as "men" and "mankind.

- "Reign" to substitute for "kingdom," as in the "reign of God" instead of the "kingdom of God."

The inclusive language movement seems to have had a major effect in English. St. Mary's Press includes many of the above changes in its English publications. The word "padre/father," for example, rarely appears unless it is quoted from the Bible (the New Jerusalem Bible or the New Revised Standard Version). The term "padre" is more ingrained in Hispanic culture and thus appears more frequently in Spanish texts than does "father" in the English texts. For example in the book Seguidores de Jesús/Followers of Jesus, one of the headings appears in Spanish as "La voz del Padre y las tentaciones humanas" (41), while in English it appears as "God's voice and human temptations" (41).

Some words in English such as "man/woman," "boy/girl," and "brother/sister" are intrinsically masculine or feminine, but this is not necessarily so in Spanish. 
Many of the changes proposed by the inclusive language movement are easily adopted in English, with its minimal gender marks in comparison to Spanish. Since Spanish differentiates gender in most of its words, it has been a challenge to adopt inclusive language, since the masculine form is customarily used as the generic term. Some extreme examples are:

- Los muchachos y las muchachas, "the boys and the girls," when in Spanish "los muchachos" can work as a generic term.

- Queridos hermanos y hermanas, "dear brothers and sisters," when in Spanish "hermanos" can work as a generic term.

- Queridos padres y madres, "dear parents," when in Spanish "padres" can work as the generic term.

In Spanish use of the diagonal (/) may be an option: el/la estudiante, el/la religioso(a); but this option has been criticized by editors and readers, who feel the use of hyphenation or parenthesis disrupts the process of reading.

The influence of English on Spanish-language translation in the United States sometimes causes confusion among publishers who have committed to a more inclusive use of the language in their publications in English. Even some of the changes in Spanish that are considered to be more inclusive are marked by gender:

el hombre ha sido creado a imagen de Dios $\rightarrow$ el ser humano...

man is created in God's image $\rightarrow$ human beings...

Although this example seems a good solution in Spanish, since "ser humano" is not intrinsically masculine as "hombre" is, it still carries masculine grammatical gender. As for songs and hymns, Flor y canto, published by Oregon Catholic Press (OCP), is perhaps the most popular songbook among Hispanic churches in the US. This book received the input of some of the members of the Hispanic Liturgy Subcommittee. The first edition includes some interesting examples of efforts at inclusive language. One of the most famous hymns in Latin America is "Himno de la Alegría/Hymn of Joy," best known as a melody of Beethoven. Here are parts of the Latin American version and the "inclusive" version included in Flor y Canto (1989):

Latin American version

Escucha hermano la canción de la alegría...

en que los hombres volverán a ser hermanos.

OCP version

Escucha todos, la canción de la alegría

en que los todos volverán a ser unidos. 
In the OCP version the editors avoid using the words "hermano" and "hombres," which are replaced by "todos" and "unidos." The OCP version is barely comprehensible, and although it appears more gender-balanced, the words "todos" and "unidos" are still marked by masculine morphology. The OCP version was not accepted by the Hispanic communities in the US: in the new version of Flor y canto (2001), the song is still there but based on the English version, which is not related at all to the Spanish one, but has the same music:

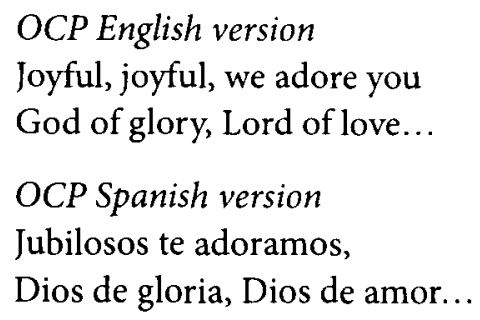

Notice the non-inclusive use of "Lord" in the English version. Another example is the song "Danos un corazón/Give us a Heart," originally titled "Hombres nuevos/ New Men":

\section{Latin American version}

Danos un corazón grande para amar,

Danos un corazón fuerte para luchar.

Hombres nuevos creadores de la historia

constructores de nueva humanidad...

OCP version

Danos un corazón grande para amar,

Danos un corazón fuerte para luchar.

Pueblos nuevos creadores de la historia

constructores de nueva humanidad...

This new version appears in the new edition, while the original version appears in the 1989 edition. In the new edition "pueblos/people" takes the place of "hombres/ men." However, "pueblos" is still marked with masculine morphology. There are other examples of changes in songs. I do not know whether those changes were made in consultation with the writers of the songs. Also, the initiative of incorporating more inclusive language in the songs has not been applied to all of them. The title of the song "Pescador de hombres/Fisherman of men" - one of the most celebrated hymns in Spanish which has also been translated into English - has not been changed in the new edition of Flor y canto. One of the reasons, perhaps, is because the word "hombres" appears in the title but not in the song.

It appears that English speakers in general try to apply their rules of inclusive language to contemporary literature and documents, while some Spanish speakers 
want to make those rules retroactive and apply them everywhere. Those changes may not come from grassroots Church organizations, but rather from people in influential positions, specifically nuns and women in administrative positions and members of the Hispanic Liturgy Subcommittee. This is a very controversial and delicate topic among certain Church groups. Carson (1998) and Witherup (1996) are an excellent starting point for a more specific examination.

\section{Conclusion}

The Spanish language plays an important role in the development and growth of the US Catholic Church. Although Spanish is not considered an official language by the US Government, the Catholic Church has already made that step in order to maintain the unity and diversity of the institution, establishing language policies that respond to the needs of churchgoers. During the last decade, the provision of social and liturgical services in Spanish has been growing, and the Hispanic presence has been a sign of vitality. However, this path has not been easy: there is still opposition from those who believe in "One Church / One Language" and see Spanish as an element of division among US Catholics.

Spanish and English have gone through a process of acculturation which is evident in the lexical innovations that have affected both languages. In this study I focused mostly on some of the new words and meanings that now are part of the Spanish of the United States. The proliferation of Spanish books has also contributed to the creation and development of an educated Spanish variety, similar to other standard varieties of Spanish, but with its own characteristics.

Spanish has also gone through a process of adjustment to the changes and modalities of contemporary English. The use of inclusive language within Spanish books, documents and songs is a reflection of the changes occurring in English for more gender-balanced usage.

If the immigration of Hispanics continues to grow in the United States, it is evident that the development and growth of Spanish is going to continue as well. The arrival of new Hispanics contributes to the vitality and maintenance of the language, while second-, third- and fourth-generation Hispanics revitalize their use of the language as well. The officialization of Spanish is already a reality within the US Catholic church, and the fact that over forty percent of Catholics in the US are of Hispanic origin is an indication that Spanish has been present throughout the history of the US Catholic church and is here to stay. 


\section{Notes}

1. Statistics were drawn from the document Encuentro y misión: un marco renovado para el ministerio hispano (United States Conference of Catholic Bishops 2002), but I also consulted statistics compiled by the Subcommittee on Hispanic Affairs and the Committee on Divine Worship (Liturgy) in the USCCB. According to statistics provided by the USCCB in 2005, there are 69.1 million Catholics in the US, and 30 million are Hispanics, $43.5 \%$ of the total Catholic population.

2. I have been a member of the St. Mary's Press Hispanic Team since 1994. This team eventually became Instituto Fe y Vida. All the information provided in this section is based on my own experience, and was verified with Carmen M. Cervantes, executive director of the program.

\section{References}

Bishop's Committee on Hispanic Affairs. 1999. Hispanic Ministry at the Turn of the New Millennium. Washington, DC: National Conference of Catholic Bishops.

Carson, D.A. 1998. The Inclusive-Language Debate: A Plea for Realism. Grand Rapids, MI: Baker Books.

Cervantes, Carmen M., ed. 1994. La juventud hispana y a la respuesta pastoral de la iglesia. Winona, MN: St. Mary's Press.

Cervantes, Carmen M., ed. 1998. En alianza con Dios/In covenant with God. Winona, MN: St. Mary's Press.

Cervantes, Carmen M., ed. 2000. Seguidores de Jesús/Followers of Jesus. Winona, MN: St. Mary's Press.

Cervantes, Carmen M. 2003. Pastoral juvenil vs. youth/young adult ministry. Antonio MedinaRivera, ed. Elementos fundamentales de pastoral juvenil. Stockton, CA: Fe y Vida. 10-15.

Dolan, Jay P. 1992. The American Catholic Experience. Notre Dame: University of Notre Dame Press.

Dolan, Jay P. \& A. F. Deck. 1994. Hispanic Catholic Culture in the U.S.: Issues and Concerns. Notre Dame: University of Notre Dame Press.

Flor y canto. 1989. Portland, Oregon: Oregon Catholic Press.

Matovina, Timothy \& G. E. Poyo. 2000. $i$ Presente! U.S. Latino Catholics from Colonial Origins to the Present. Maryknoll, NY: Orbis Books.

Spolsky, Bernard. 2004. Language Policy. Cambridge, UK: Cambridge U. P.

United States Conference of Catholic Bishops. 2002. Encuentro y misión: un marco renovado para el ministerio hispano, at http://www.usccb.org/hispanicaffairs/encuentromissionsp. shtml

Witherup, Ronald D. 1996. A Liturgist's Guide to Inclusive Language. Collegeville, MN: Liturgical Press.

\section{Archives consulted}

University Archives, University of Notre Dame. Bishop Robert E. Lucey's files. 


\section{Resumen}

\section{La oficialización y la aculturación lingüistica del español en la Iglesia católica de los Estados Unidos}

El presente estudio trae a colación algunos cambios que se asocian al uso del español y el inglés en la Iglesia católica de los Estados Unidos. La primera sirve como un análisis del proceso de oficialización del español desde una perspectiva histórica. En segundo término, se examina el papel de la aculturación en el desarrollo y contacto de dos lenguas en una institución como la Iglesia católica. Finalmente, se analiza el uso del lenguaje inclusivo dentro de la Iglesia y su impacto en una lengua que está mucho más marcada por la diferencias de género que el inglés. Estos tres elementos sirven para tener una perspectiva más complete sobre la realidad, expansión, revitalización y mantenimiento del idioma español en los Estados Unidos. Asimismo pone de manifiesto algunas de las políticas lingüísticas (directas e indirectas) que han tenido un impacto en el uso del español dentro de la Iglesia católica de los Estados Unidos.

\section{Resumo}

\section{Oficialigo kaj lingva alkulturigo de la hispana en la katolika eklezio de Usono}

Tiu ĉi esploro jetas lumon al kelkaj el la ŝanĝoj ligitaj al uzo de la angla kaj hispana lingvoj en la Usona Katolika Eklezio. La unua parto ekzamenas la oficialigan procedon el historia vidpunkto, kun agnosko de la efiko de iuj grupoj aŭ asocioj rilate uzon de indiĝenaj lingvoj ene de la Eklezio. La dua parto ekzamenas la rolon de alkulturigo dum tiu oficialiga procedo; kaj la fina sekcio analizas la uzon de inkluziva lingvajo en la Eklezio, kiel klopodo atingi pli sekse ekvilibran institucion. Tiuj tri elementoj liveras pli kompletan perspektivon de la efektivo, ekspansio, revivigo kaj daŭrigo de la hispana lingvo en Usono. La artikolo ankaŭ malkaŝas iujn lingvoplanajn politikojn (rektajn kaj nerektajn), kiuj jam havis sian efikon je la utiligo de la hispana ene de usona katolikismo.

\section{Author's address}

Cleveland State University

Department of Modern Languages

2121 Euclid Avenue

Cleveland, $\mathrm{OH} 44115$, USA

a.medinarivera@csuohio.edu

\section{About the author}

Antonio Medina-Rivera is Associate Professor of Spanish and Linguistics, and Director of Cultural Crossings, in the Department of Modern Languages at Cleveland State University. His areas of interest include Spanish in the US, US Hispanic literature, Puerto Rican Spanish, Puerto Rican literature, and cultural studies. Dr. Medina-Rivera organizes the biennial Crossing Over Symposium in Cleveland, bringing scholars from the US and other parts of the world for interdisciplinary dialogue. 